\title{
Ice-Rafted Detritus Events in the Arctic During the Last Glacial Interval, and the Timing of the Innuitian and Laurentide Ice Sheet Calving Events
}

\author{
Dennis A. Darby \\ Old Dominion University, ddarby@odu.edu \\ Paula Zimmerman \\ Old Dominion University
}

Follow this and additional works at: https://digitalcommons.odu.edu/oeas_fac_pubs

Part of the Glaciology Commons, and the Oceanography and Atmospheric Sciences and Meteorology Commons

\section{Repository Citation}

Darby, Dennis A. and Zimmerman, Paula, "Ice-Rafted Detritus Events in the Arctic During the Last Glacial Interval, and the Timing of the Innuitian and Laurentide Ice Sheet Calving Events" (2008). OEAS Faculty Publications. 18.

https://digitalcommons.odu.edu/oeas_fac_pubs/18

\section{Original Publication Citation}

Darby, D. A., \& Zimmerman, P. (2008). Ice-rafted detritus events in the Arctic during the last glacial interval, and the timing of the Innuitian and Laurentide ice sheet calving events. Polar Research, 27(2), 114-127. doi: 10.1111/j.1751-8369.2008.00057.x 


\title{
Ice-rafted detritus events in the Arctic during the last glacial interval, and the timing of the Innuitian and Laurentide ice sheet calving events
}

\author{
Dennis A. Darby \& Paula Zimmerman \\ Dept. of Ocean, Earth, and Atmospheric Sciences, Old Dominion University, Norfolk, VA 23529, USA
}

\begin{abstract}
Keywords
Arctic Ocean; ice-rafting events; glacial collapses; sea ice; Fe grain provenance.

\section{Correspondence}

D.A. Darby, Dept. of Ocean, Earth, and Atmospheric Sciences, Old Dominion University, Norfolk, VA 23529, USA.

E-mail: ddarby@odu.edu
\end{abstract}

doi:10.1111/j.1751-8369.2008.00057.x

\begin{abstract}
Ice-rafted detritus (IRD) layers in the Arctic Ocean not only indicate the source of this detrital sediment, but give insights into the ice drift and ice sheet history. Detrital sand-sized Fe oxide mineral grains that are matched to precise sources using the microprobe chemical fingerprint of each grain, along with elevated coarse IRD abundance and radiocarbon ages, are used to define IRD peaks from the Innuitian and Arctic portions of the Laurentide ice sheets. Because grains from these two areas can be entrained by sea ice from the shelves just offshore of the calving areas, peaks in these grains must be correlated to coarse IRD to identify iceberg calving events, and to distinguish them from sea-ice rafting. The sequence of IRD peaks deposited by icebergs from these two ice sheets indicate that both ice sheets calved bergs at accelerated numbers, six or seven times, from 11 to $36 \mathrm{Kya}$. The relatively short times between most of these IRD events suggest that the ice sheets did not completely collapse with each IRD event, except the last event. Although there is some indication that one ice sheet may have begun calving bergs before the other, the resolution of the Arctic cores does not allow definitive determination of this. This emphasizes the need for higher resolution cores from the central Arctic, as well as from near the terminus of large Pleistocene ice sheets. Sea-ice rafting occurs throughout the last glacial stage, even during some glacial IRD events, as indicated by Fe grains from non-glacial sources.
\end{abstract}

Palaeoceanographic research on marine ice-rafted detritus (IRD) is amassing substantial evidence that Pleistocene ice sheets do not ablate slowly and continuously over thousands of years, but tend to partially collapse very rapidly in a series of dramatic events producing voluminous numbers of icebergs and extensive layers of IRD, such as the Heinrich layers in the North Atlantic (e.g., Grousset et al. 1993; Rashid et al. 2003). The Arctic ice sheets have only recently been shown to have collapsed in a similar fashion, and perhaps in synchrony with North Atlantic ice sheets (Darby et al. 2002; Stokes et al. 2005). Recognition of these collapse events has raised the obvious question as to why large ice sheets collapse suddenly, and several theories have been proposed (MacAyeal 1993; Bond \& Lotti 1995; Fronval et al. 1995; Johnson \& Lauritzen 1995; Marshall \& Clarke 1997; Scourse et al. 2000; Grousset et al. 2000; Hulbe et al. 2005). Identifying such IRD events in the Arctic is not straightforward because of the abundance of IRD from both sea ice and glacial rafting. Establishing the timing of rapid calving events is particularly important in order to understand the behaviour of large ice sheets, but also to develop a palaeoclimatic history in the Arctic.

This paper revisits the findings from the Arctic Innuitian IRD events, and their relationship to the IRD events from the Arctic portion of the Laurentide Ice Sheet (ALIS), with additional data and the examination of more cores. Distinguishing glacial IRD events from sea-ice IRD events poses a significant problem. Linking ALIS and Innuitian Ice Sheet (IIS) calving events to coarse IRD, and to generally low numbers of grains from non-glaciated areas such as the Laptev Sea, can help to resolve this problem. The timing and length of time between the glacial IRD events in several cores could also lead to new insights into the nature of these IRD events, and whether they represent extensive collapses of the ice sheets. There 
is still some question as to whether the IIS calved icebergs prior to the ALIS, and arguments that the decay of this much larger ice sheet actually caused the destabilization of the much smaller IIS (England et al. 2006) require further examination of the stratigraphic position of IRD peaks attributed to the IIS and ALIS peaks.

Whereas Heinrich $(\mathrm{H})$ events have been equated to major ice sheet collapses because of the widespread occurrence of these layers in the North Atlantic, as well as the generally brief time span for these events (Bond et al. 1992; Dowdeswell et al. 1995), the reasons for these ice sheet collapses are still being debated. Potential explanations include: internal dynamics of ice sheets, i.e., binge and purge cycles during which an ice sheet becomes unstable and rapidly calves a large portion of its volume (MacAyeal 1993); glacial growth on sensitive margins during periods of atmospheric cooling, leading to increased calving during warmer periods (Bond $\&$ Lotti 1995); the storage of meltwater at the base of the ice sheet until frictional forces are overcome (Johnson \& Lauritzen 1995); surges of ice streams caused by factors such as the increased lubrication of the basal surfaces of glaciers, including a sea level rise (Marshall \& Clarke 1997); and the catastrophic loss of a buttressing ice shelf (Hulbe et al. 2005).

\section{Cores and methods}

The core, PS 1230, used to initially reveal the IRD peaks as rapid calving or collapse events from the ALIS and IIS, as well as the IIS events possibly preceding those of the ALIS, is reanalysed to add more detail. This core is from Fram Strait near the centre of the Arctic Ocean drift-ice outflow. Like nearly all of the cores from the Arctic, this core has fairly low sedimentation rates, averaging about $1 \mathrm{~cm} \mathrm{Ky}^{-1}$. Two additional cores are included from this important exit corridor for ice (Fig. 1). Three other cores from the central Arctic ridges and one from the Chukchi Borderland (Northwind Basin) are included to provide breadth to the study. All but one of these cores (PS1231) have age models based on accelerator mass spectrometry (AMS) radiocarbon dates (Darby et al. 1997; Darby et al. 2002; Nørgaard-Pedersen et al. 2003), and this one core is correlated to a nearby dated core (PS1230) using key lithostratigraphic indicators such as colour bands, coarse IRD content, planktic foraminifer abundance and mineralogic content in the IRD fraction. All ages are reported as calendar years with the standard 400-year marine reservoir correction $(\Delta R)$, and were converted to calendar years by CALIB 5.0.2 (Stuiver et al. 1998) or by referring to Fairbanks et al. (2005) if the ages were $>24$ Ky. Reservoir corrections are not well established for the Arctic, but the Svalbard area near Fram Strait has a $\Delta R$ of about 40
(Mangerud \& Gulliksen 1975) in the CALIB database (Reimer et al. 2004), and other studies found $\Delta R$ to be about the same for the coastal waters of the LaptevBarents seas area (Forman \& Polyak 1997; Bauch et al. 2001 ). Without any other studies of reservoir corrections in the central Arctic and Northwind Basin areas, and with the knowledge that the many planktic foraminifer used to date these cores calcify in the lower halocline (HillaireMarcel et al. 2004), we use the standard 400-year correction $(\Delta R$ of 0$)$, similar to that of the North Atlantic.

The coarse fraction percentage can often vary over short distances because of the vagaries of IRD deposition, such as iceberg load, melt-out rates and drift tracks (Andrews 2000). Iron-grain chemical fingerprinting is used in this study to match individual sand-sized Fe oxide grains to glacial ice sheets, and to designate IRD deposition from various ice sheets (Darby et al. 2002). This provenance technique provides robust identification of precise sources, with as little as between five and eight grains required for a positive match (Darby 2003). The percentage of Fe grains matched to a particular source or ice sheet avoids ambiguities in ice sheet IRD when more than one source is involved, as is usually the case. Unlike in the earlier study, in which peaks in Fe grains matched to the IIS and ALIS did not always correspond to elevated percentages of coarse IRD (Darby et al. 2002), we use only peaks associated with elevated (sometimes slightly elevated) quantities of coarse IRD, preferably $>250 \mu \mathrm{m}$ in diameter, or coarser where data on these larger size fractions are available. In addition we look at whether significant numbers of Fe grains in these IRD events are from sources that were never glaciated, such as the Laptev Sea. The Fe grain fingerprinting involves microprobe analyses of 12 elements in nine different varieties of Fe oxides, followed by matching each grain to a source composition for that mineral in potential sources using discriminant function analysis, such that the composition of the source group is identical to that of the matched grain within limits that approach reproducibility by microprobe (Darby \& Bischof 1996; Darby 2003). The grains are matched to a large database of circum-Arctic source areas consisting of more than 2000 composition groups (Darby 2003). The IIS and ALIS are well characterized by this database, and contain unique Fe grain compositions that are easily distinguishable. In fact, different parts of the calving areas of these ice sheets can be readily distinguished (Stokes et al. 2005).

Most cores are sampled at every centimetre, except where noted, and the Fe grains are magnetically removed from the 45-250- $\mu \mathrm{m}$ fraction after wet sieving (Darby \& Bischof 1996). The Fe grains are mounted in epoxy plugs, ground to expose the centre of the grains, polished, microscopically identified (1000× magnifica- 


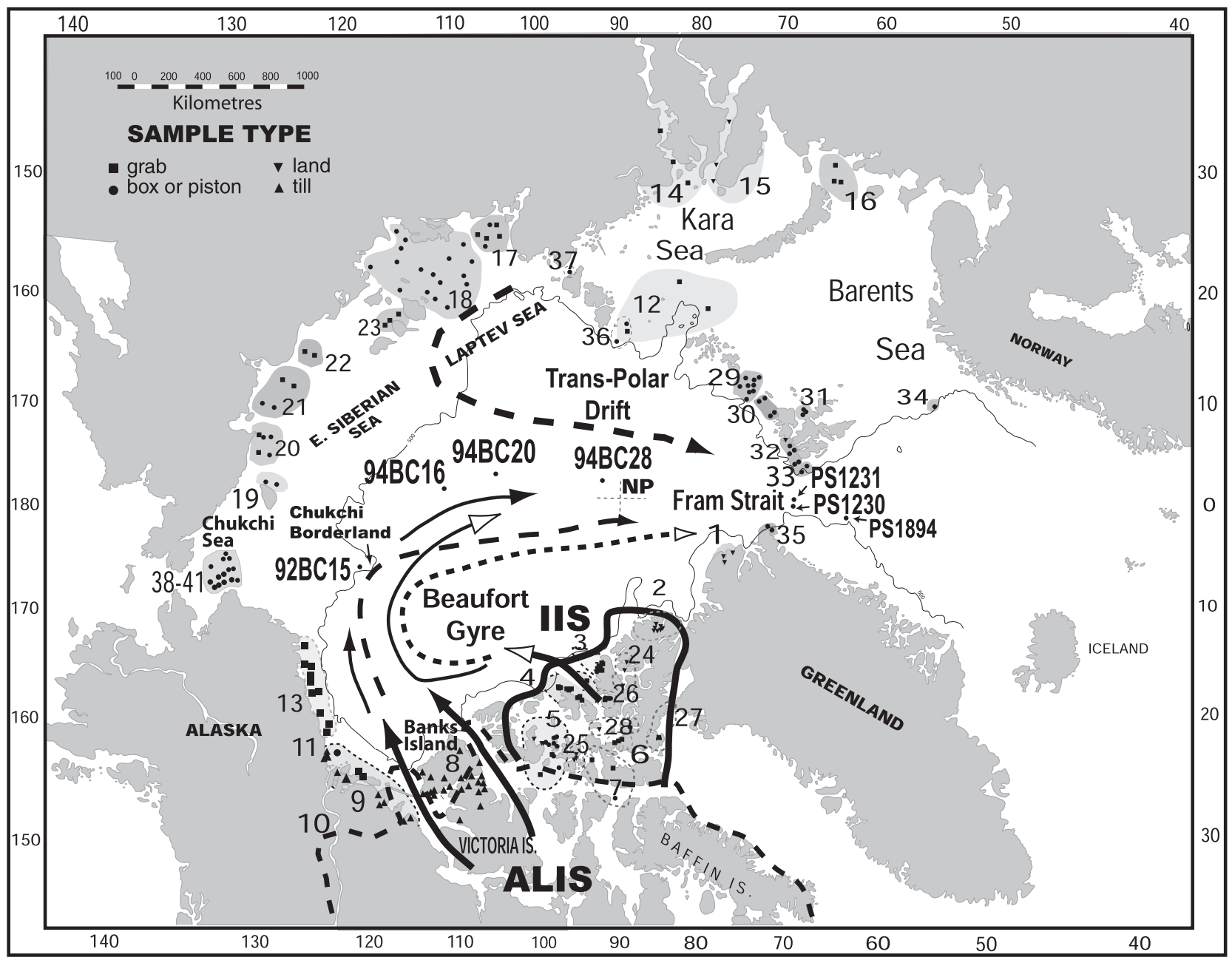

Fig. 1 Location of core sites and circum-Arctic source areas 1-41 and source sample sites. The major outlets for the Arctic portion of the Laurentide Ice Sheet (ALIS; filled arrows) and the Innuitian Ice Sheet (IIS; open arrows) are shown, along with probable drift tracks for icebergs from these two ice sheets. Probable drift paths (thin dashed lines) are shown after ice that became grounded on the Chukchi Borderland blocked the ice drift in this area.

tion), numbered on a photograph and analysed by an automated electron probe microanalyser for 12 element oxides, using oxide standards, with a beam diameter of about $5-20 \mu \mathrm{m}$, in order to obtain an average composition for each grain. The grains are matched to every composition group in the source database, with the source area determined by a probability of 0.95 for group membership, and with a probability of 0.5 or better indicating that the grain is closer to the group centroid than the grains that were used from the source area to establish that group. The groups have been tested to insure that the standard deviation of each element is less than $3-5 \%$ of the actual value, and each matched grain is less than this because of the probabilities used to screen the grains. Only about $60 \%$ of the source-area Fe grains analysed were used to form the more than 2000 compositional groups with 3-150 grains in each group.
A total of 15000 grains were analysed for this source database, and fewer than $8 \%$ of these match into groups from other circum-Arctic areas (Darby 2003). Typically $50-60 \%$ of the grains analysed from core samples will be successfully matched to a circum-Arctic source. The large percentage of unmatched grains results from several factors, including: (1) the criteria used to match grains into source groups where a matched Fe grain must be closer to the group centroid than half the grains that form the source group; (2) the fact that grains might come from circum-Arctic areas that have yet to be characterized; (3) multi-phased Fe oxide minerals where the proportion of each phase analysed in the beam influences the grain composition, making these grains difficult to match; and (4) vagaries in the probe analyses. The use of the two probabilities insures that forced matches do not occur, and that chance composi- 
tional matches are very few. Because less than the desired statistical number of 300 grains are matched, a weighted percentage is used, where the number of grains matched to a source is multiplied by the percentage matched to that source area and divided by 10 (nearly twice the number of grains needed for a positive match), so as to avoid anomalously large percentages when grain numbers are low. Although this usually prevents erroneous percentage peaks, the actual number of Fe grains matched to the ALIS and IIS is also plotted to insure that peaks contain significant numbers of grains (between five and eight); here, the minimum is set at seven grains matched to a source area.

Because sea ice can transport very coarse IRD, on occasion, the distinction of sea-ice versus glacial IRD is very difficult. In an attempt to help with this problem, we have included Fe grains from the southern Queen Elizabeth Islands (QEI) along with Fe grains from the northern QEI as designating the IIS. Thus, source areas 5, 6, 7, 25 and 28 are added to areas 2, 3, 4, 24 and 26 (Fig. 1) used by Darby et al. (2002), because these additional source areas would probably not contribute to the Arctic by sea-ice rafting, because sea-ice entrainment is restricted to the northern QEI shelves, and possibly to some of the northern QEI fjords. Few of the southern QEI Fe grains are found on the QEI Arctic shelf (Bischof \& Darby 1999). Southern QEI Fe grains would only get into the Arctic during glacial calving events into the Arctic, where grains from these southern areas had a chance to flow into the Arctic when the IIS flowed in this direction (England et al. 1991). Although these added source areas contributed less than half of the IRD that the northern QEI areas contributed to the Arctic cores studied, they do influence the position of peaks during IRD events, and result in differences in peak position and height. For example, the peaks in core PS1230 are generally in the same depth range as previously reported (Darby et al. 2002), but the new criteria and additional analyses result in some differences. Likewise, to be more representative of the ALIS, source areas 9 and 10 were added to that of source area 8 (Fig. 1) used in the earlier study (Darby et al. 2002). This better represents the Amundsen Gulf outflow from the ALIS. Finally, Fe grains matched to the Laptev Sea are compared with the coarse IRD peaks in all cores that contain either an ALIS or IIS peak not corresponding to a coarse IRD peak, in order to determine if these Fe grain peaks might be sea-ice rafted, and to test whether any of the coarse IRD peaks might at least include sea-ice rafted Fe grains. This is based on the fact that the Laptev Sea is an important modern source of sea-ice entrainment, and the assumption that it would be so in the past, and the fact that there is no solid evidence that it was ever glaciated (Darby 2003).

\section{Results}

\section{Fram Strait cores}

Fram Strait is the major outlet of the Arctic Ocean, and nearly all of the ice today flows out between $0^{\circ}$ and $10^{\circ} \mathrm{W}$. Cores PS 1230 and PS1231 are located at about $5^{\circ} \mathrm{W}$ or near the centre of this outflow (at depths of 2700 and $2012 \mathrm{~m}$, respectively), whereas PS1894 is located $354 \mathrm{~km}$ to the south at $8.3^{\circ} \mathrm{W}(1975 \mathrm{~m})$. Thus, these cores are ideally located to record the outflow of ice from the Arctic Ocean. PS1230 has an average sedimentation rate of $1.5 \mathrm{~cm} \mathrm{Ky}^{-1}$ down to the bottom of this box core at about 33.5 Kya, except for a 5 -cm interval between 17.5 and 19 Kya that averages at $5.6 \mathrm{~cm} \mathrm{Ky}^{-1}$. Less than $18 \mathrm{~km}$ from PS 1230, core PS 1231 has a sedimentation rate based on its correlation with PS1230 of $1.4 \mathrm{~cm} \mathrm{Ky}^{-1}$ down to $20 \mathrm{~cm}$, where the rate increases slightly.

PS 1894 was sampled at 2-cm intervals except between 33 and $39 \mathrm{~cm}$, where it was sampled at every centimetre. The sedimentation rate in the upper $40 \mathrm{~cm}$ of PS1894 is $2.6 \mathrm{~cm} \mathrm{Ky}^{-1}$, but below this it increases to about $21 \mathrm{~cm} \mathrm{Ky}^{-1}$, and thus only seven samples were analysed between 55 and $90 \mathrm{~cm}$ (19-20.5 Kya). All three of these cores are within the modern perennial ice cover, and would have been under presumably even heavier ice coverage during the last glacial stage. This probably accounts for the generally low sedimentation rates, except during some IRD events. Incursions of warm water into the Fram Strait area, especially near PS1894, are possible, and this could cause increased melt/ sedimentation rates below $40 \mathrm{~cm}$ in this core.

The three Fram Strait cores contain between four and seven IRD events, defined by rapid increases in Fe grain abundances matched to the IIS or the ALIS, and elevated percentages of coarse IRD (Fig. 2). Both cores from the centre of the Fram Strait ice drift (PS1230 and PS1231) contain similar average abundances of coarse IRD for all IRD events, as well as similar numbers of Fe grains matched to the North American ice sheets. Core PS 1894 contains much lower levels of coarse IRD and Fe grains (Figs. 2, 3). The first three IRD events in PS1894 do not show increased coarse IRD, and show only small peaks in the number of grains matched to the IIS and ALIS. This emphasizes the vagaries of IRD deposition, in which some cores only a few hundred kilometres away do not record IRD events in a similar manner, perhaps because of drift paths or differences in where ice melts. Even cores PS1230 and PS1231, which are only $18 \mathrm{~km}$ apart, do not contain the same percentage of coarse IRD in most of the IRD events (Fig. 3). All of these cores contain significant coarse IRD peaks during the last $10 \mathrm{Ky}$ that are probably caused by sea-ice rafting dominated by anchor ice, which 


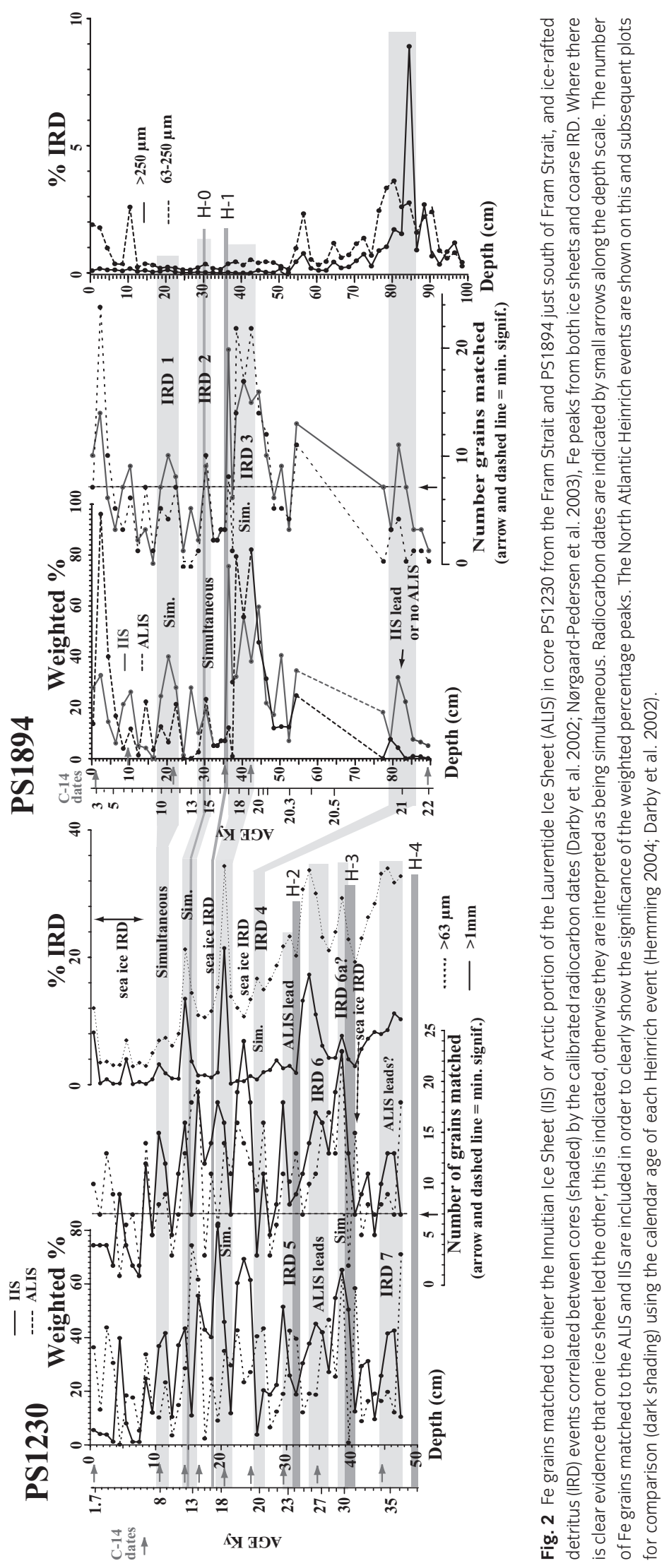




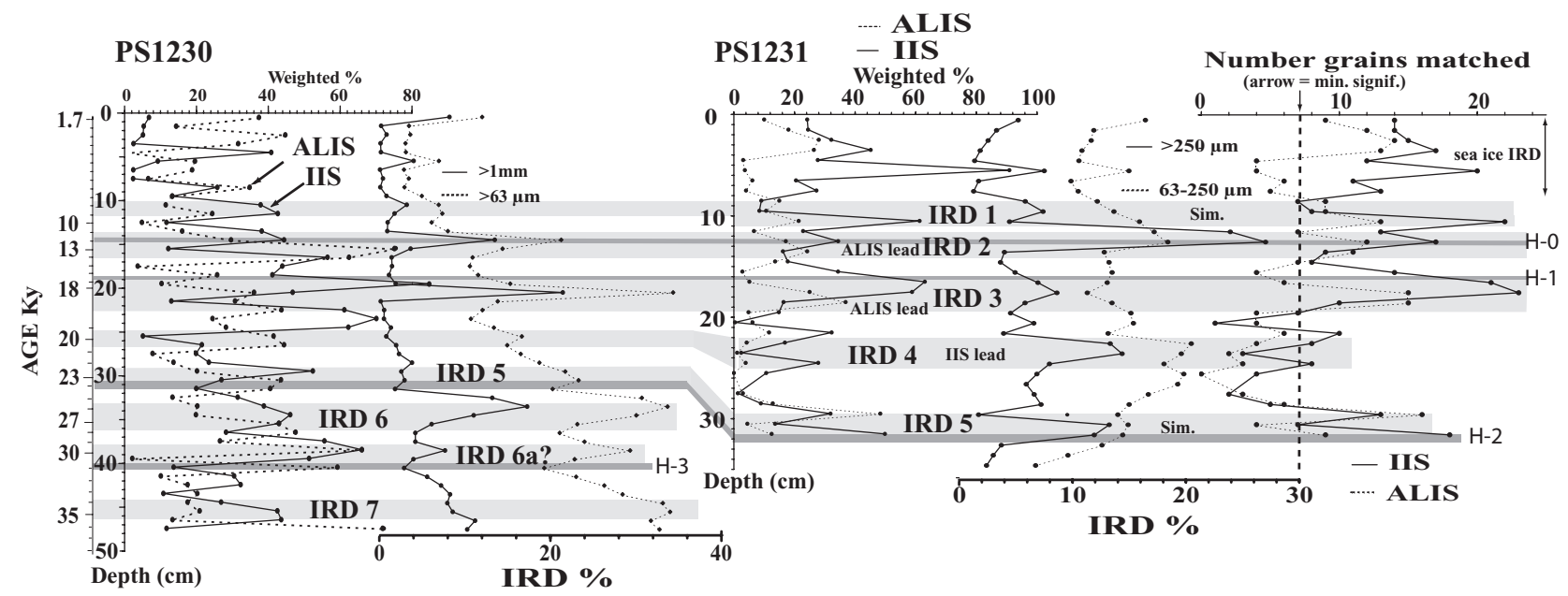

Fig. 3 Correlation of five ice-rafted detritus (IRD) calving events between cores PS1230 and PS1231 from Fram Strait.

can entrain very coarse sediment from water depths up to about $30 \mathrm{~m}$ (Reimnitz et al. 1987). This indicates that coarse IRD alone is an unreliable indicator of glacial IRD events, and this problem is exacerbated by using samples of relatively small volume that may not be representative of the coarser size fractions. Several Fe grain peaks in PS1230 that matched to the North American ice sheets (ALIS and IIS) do not coincide with coarse IRD peaks, and these are tentatively designated as sea-ice rafting events (Fig. 2).

Determining whether the ALIS or the IIS began calving before the other is not straightforward in cores with such low sedimentation rates, especially if these rates can vary during IRD events. Thus, only where the ALIS or the IIS peak is within a centimetre or two of the other source, and is within the boundaries of the same coarse IRD peak, is a source ice sheet indicated as having led. There are several occasions when a result indicating that one ice sheet began calving before the other is questionable, and this is indicated in the plots.

All three of the Fram Strait cores show that the ALIS and IIS increase at about the same time in IRD 1. Only PS1231 shows an ALIS rise that begins and peaks prior to the IIS at IRD 2. Cores PS1230 and PS1231 show that the ALIS peaked before the IIS in IRD 3, but PS1894 shows there was a simultaneous input from both ice sheets. Again, the two closest cores show a simultaneous influx of Fe grains from the ALIS and IIS at IRD 4, and PS 1894 shows either an IIS lead or a simultaneous input where the ALIS peak is not significant. Core PS1230 shows an ALIS lead in IRD 5, 6 and, possibly, 7. Event 6a may be part of IRD 6 in PS1230 because of the apparent short time between these events and the lack of any similarly aged peak in any other core.

\section{Central Arctic cores}

Three cores are included from the central Arctic, one each from the Lomonosov Ridge (core 94BC28), Mendeleev Ridge (core 94BC16) and the Podvodnikov Basin (core 94BC20) (Fig. 1). These cores are located on the periphery of the modern Beaufort Gyre ice drift, where it joins the Transpolar Drift (Rigor \& Colony 1997). As such, they are sensitive to changes in drift tracks and mixing of ice from these two drift regimes (Fig. 1). Sedimentation rates in these cores change dramatically, from about $1 \mathrm{~cm} \mathrm{Ky}^{-1}$ in the Holocene to generally less than half this value during oxygen isotope stage 2 (OIS 2), except during rapid calving events, when rates can average up to $8 \mathrm{~cm} \mathrm{Ky}^{-1}$ (Darby et al. 1997).

Core 94 BC28 contains $2-6 \%$ coarse IRD $(63-250 \mu \mathrm{m})$ during the Holocene that does not change until after 13.5 Kya, where it then decreases (Fig. 4). Only prior to 40 Kya does this core show significant coarse IRD. Assignment of glacial IRD events is difficult in this core based solely on coarse IRD. The IRD events are therefore designated based on their age correlated with the Fram Strait cores, and Fe grain peaks matched to the ALIS and IIS, as well as with subtle increases in coarse IRD. Whereas IRD events $1-4$ can be identified, older events are difficult to link to a specific IRD event, and there are several possible sea-ice rafting events with more than the minimum number of Fe grains from either the ALIS or IIS that occur between these glacial IRD events. Only during the IRD event below IRD 4 does this core show a clear lead for either ice sheet. This older IRD event shows an IIS lead, but is poorly constrained by radiocarbon ages that are essentially somewhere beyond 40 Kya (Fig. 4). 
94BC28 Lomonosov Ridge

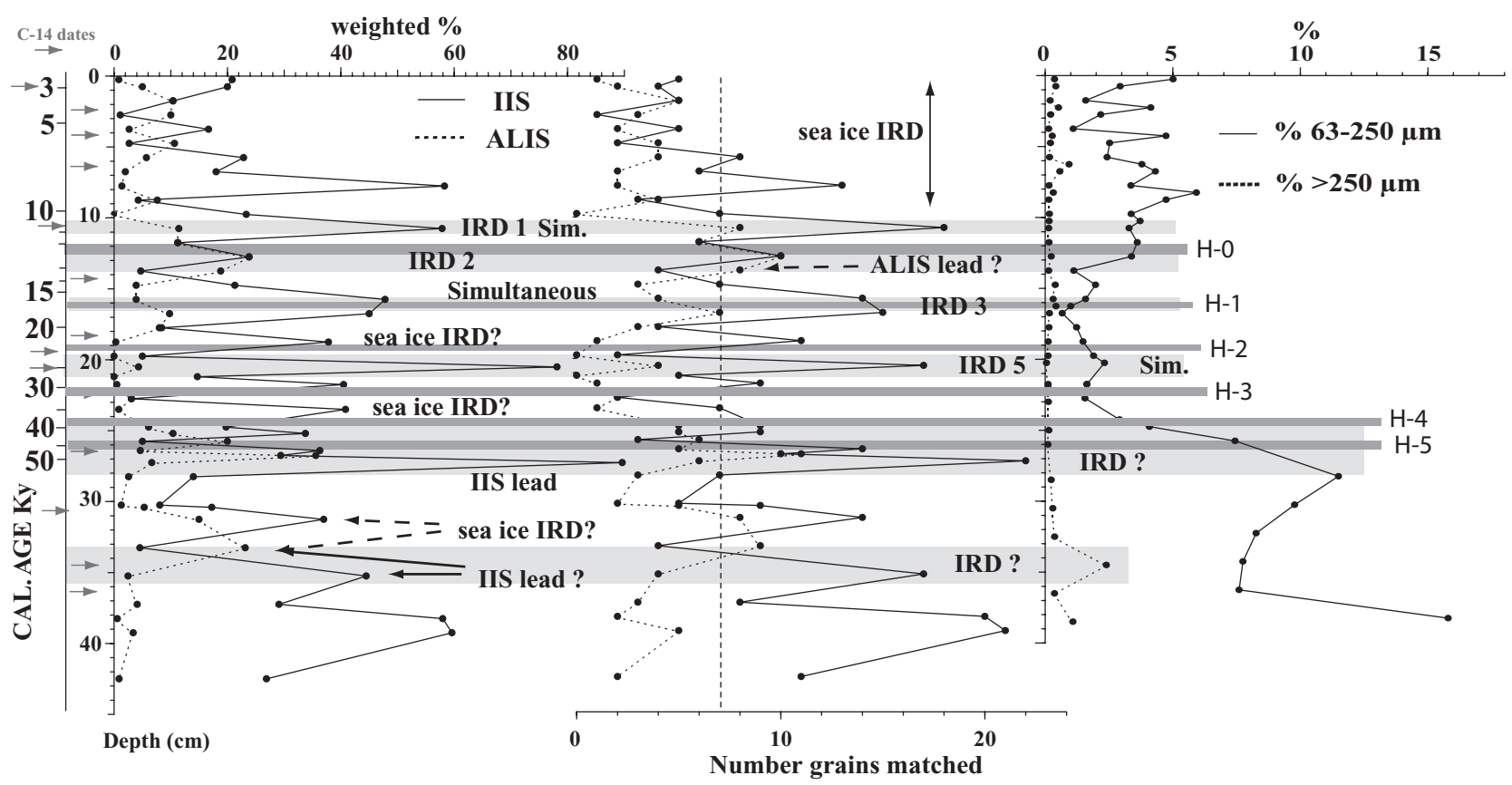

Fig. 4 Ice-rafted detritus (IRD) events in core 94BC28 from the Lomonosov Ridge. IRD 4 is apparently missing, based on the age scale. Several sea-ice IRD events are tentatively indicated between glacial IRD events.

Core 94BC20 contains a lower sedimentation record $\left(<0.5 \mathrm{~cm} \mathrm{Ky}^{-1}\right)$ than any of the central Arctic cores (Fig. 5). Only IRD events 1, 5 and 7 can be identified, and event 5 is uncertain, and could even be event 6 . Despite this, it displays fairly good correlation between Fe grain and coarse IRD peaks. The sampling interval between 18 and $30 \mathrm{~cm}$ in this core is too sparse to resolve a peak in the coarse IRD at $26 \mathrm{~cm}$. No ALIS or IIS peaks occur between coarse IRD peaks. The first coarse peak prior to $10 \mathrm{Kya}$ (IRD 2) is at about $11.5 \mathrm{Kya}$, and shows a clear ALIS lead over the IIS, but the number of ALIS grains are barely significant, and the IIS number is below that required for a definite identification of the source. The next peak (IRD 5), at about $27 \mathrm{Kya}$, shows a clear IIS lead, and the next two older IRD events show both ice sheets appearing at the same time, and another IRD event below $30 \mathrm{~cm}$ contains no significant number of ALIS grains.

Core 94BC16 has a much higher number of analysed grains compared with BC20, and has slightly higher sedimentation rates, averaging about $0.8 \mathrm{~cm} \mathrm{Ky}^{-1}$ (Fig. 6). Because of this fairly low sedimentation rate, the IRD event 4 is designated as such instead of event 3 based on the age of this IRD event, and the similarity in age with this event in other cores. Thus, IRD events 3, 5 and 6 are missing based on the age model for this core. This core also shows fairly good agreement between coarse IRD peaks (events) and Fe grain peaks from the ALIS and IIS. There are two depths (14-15 and $18 \mathrm{~cm}$ ) where IIS and ALIS Fe grain peaks do not coincide with coarse IRD, and these are tentatively designated as possible sea-ice rafting events. IRD 1 shows both ice sheets as simultaneous, IRD 2 contains no IIS peak, IRD 4 shows the IIS leading, provided that the ALIS peak just below this IRD event is the result of sea-ice rafting and not icebergs, IRD 7 clearly shows the IIS leading and bracketing an ALIS peak, and the oldest IRD event clearly shows the ALIS leading.

Like the other two central Arctic cores in this study, 94BC16 contains Holocene coarse IRD peaks that are comparable with IRD events 1-4. Only the oldest IRD events (>30-50 Kya) in these central Arctic cores contain coarse IRD percentages significantly higher than some peaks in the Holocene.

\section{Chukchi Borderland/Northwind Basin}

Core 92BC15 from the Northwind Basin, a downdropped basin within the Chukchi Borderland, contains only datable material down to a depth of $12 \mathrm{~cm}$ (12 Kya; deVernal et al. 2005), and the IRD events are therefore not constrained by age, and are numbered in sequence with question marks (Fig. 7). Unlike the central Arctic cores, it does contain large numbers of Fe grains matched to the ALIS and IIS, and peaks in these sources coincide 


\section{BC20 Podvodnikov Basin}

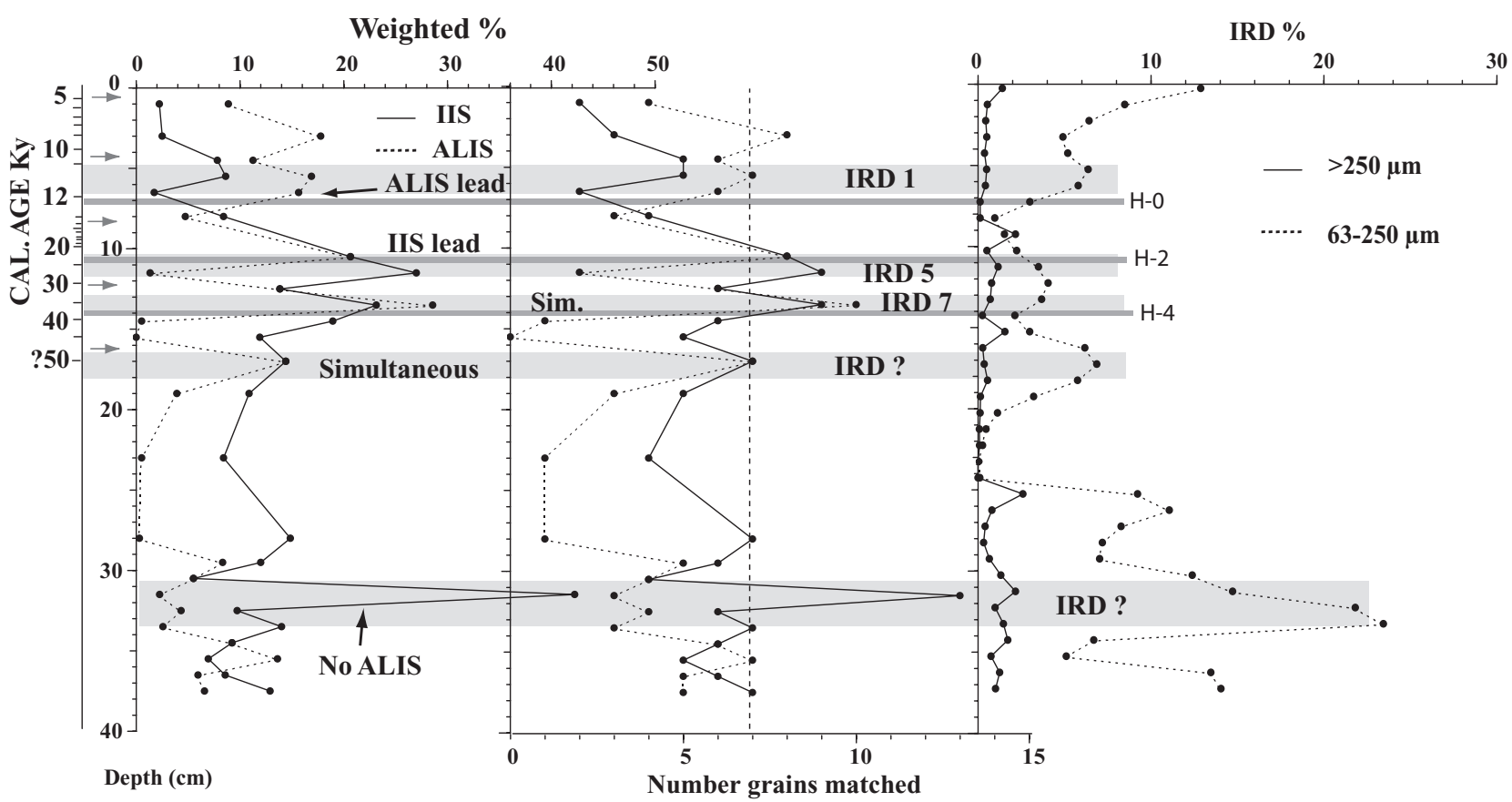

Fig. 5 Core 94BC20 is missing several ice-rafted detritus (IRD) events and has low grain numbers, despite similar sample volumes to other cores, and as such this core may denote the outer (southern) boundary of ice drift from the North American ice sheets.

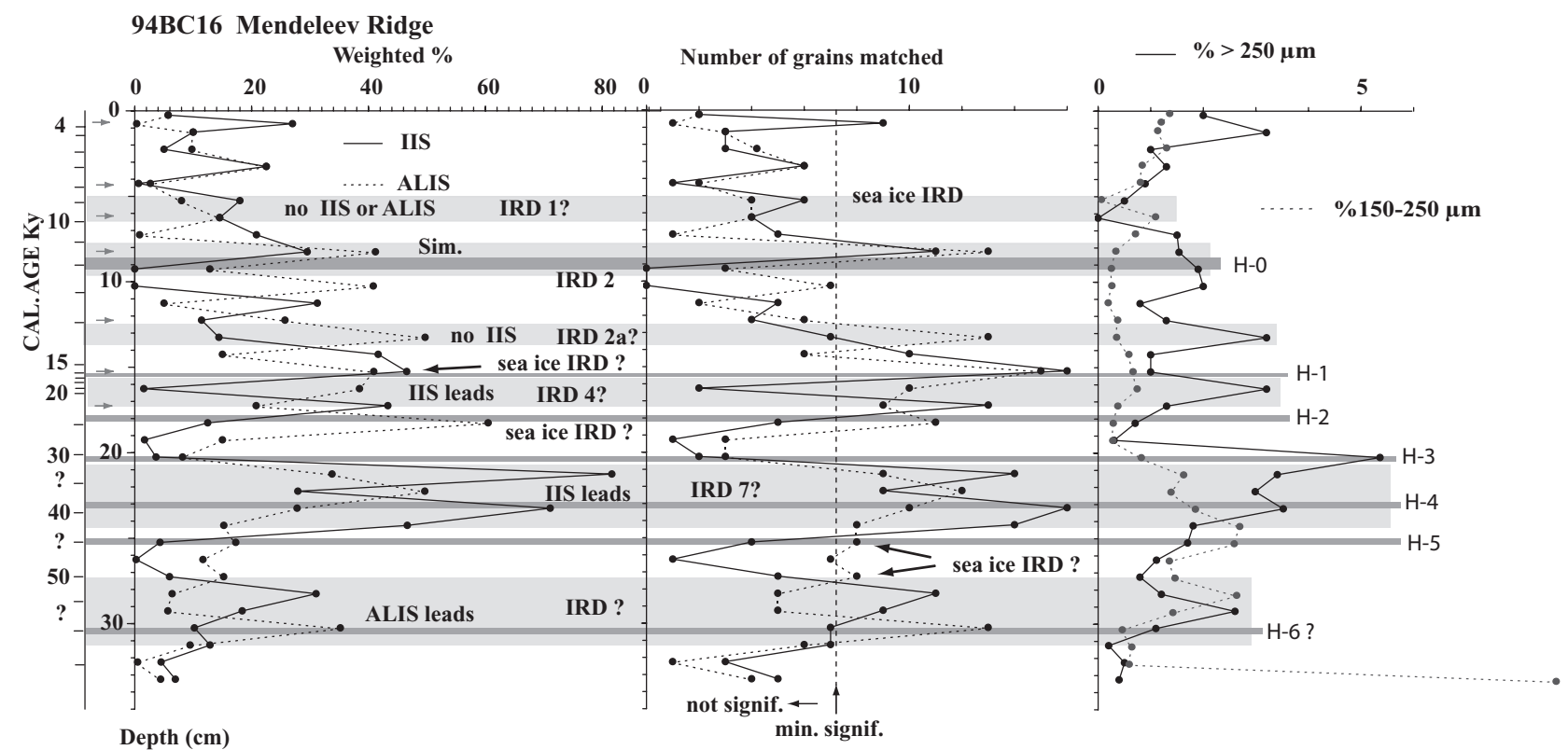

Fig. 6 Core 94BC16 from the Mendeleev Ridge contains higher grain numbers than 94BC20, but still has low coarse ice-rafted detritus (IRD) percentages. Like other cores from the central Arctic, it is missing some IRD peaks.

nicely with large peaks of coarse IRD. Although this core location is much deeper than any grounded ice in this area, it might have received some sediment from erosion of the shallower parts of the Chukchi Borderland, where ice was grounded to depths in excess of $450 \mathrm{~m}$ (Polyak et al. 2001, 2007). The coarse IRD events in this core contain large quantities of carbonate grains and Fe grains matched to the ALIS and IIS, suggesting that they are 


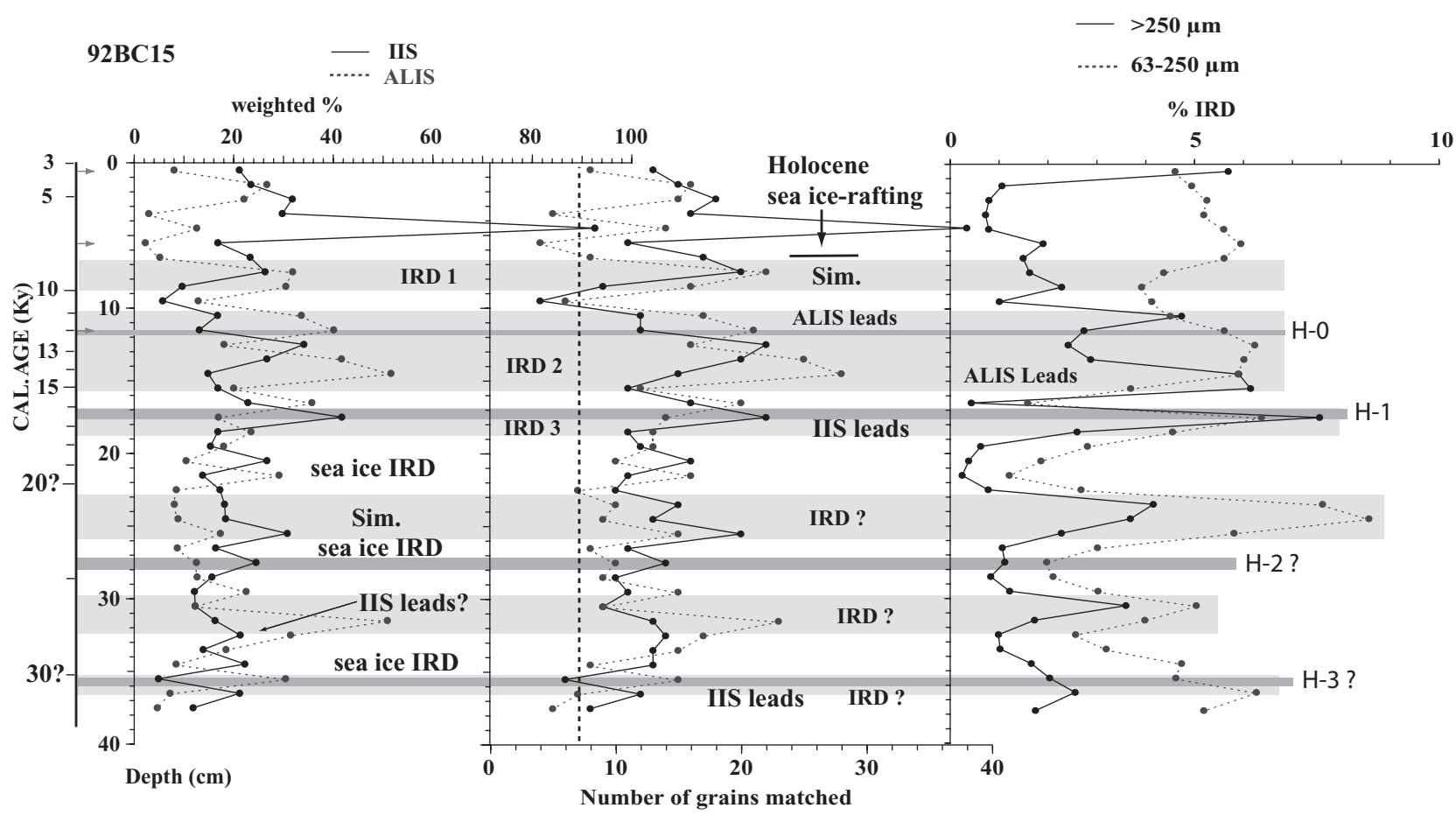

Fig. 7 Core 92BC15 is from near a site where a massive iceberg or ice shelf was grounded during past glacial stages, but is from a deeper water depth than any of the groundings. It contains higher numbers of Fe grains from the North American ice sheets than the central Arctic cores, but, surprisingly, some Fe grain peaks coincide with low coarse ice-rafted detritus (IRD), suggesting sea-ice rafting events reached an area where massive icebergs were grounded during OIS 2.

mostly ice rafted and not reworked Cenozoic sediment from the Chukchi Borderland, which does not contain carbonate sources. This core shows a possible ALIS peak leading a weak IIS peak in IRD 1, and the opposite in IRD 3 and the two oldest IRD events at 32 and $36 \mathrm{~cm}$. Small peaks of Fe grains from both the IIS and ALIS occur between IRD events in this core, and these peaks do not coincide with coarse IRD peaks (Fig. 7). These have tentatively been designated as sea-ice rafting events.

\section{Discussion}

\section{The drift of icebergs in the Arctic}

Today, the drift time to Fram Strait for ice off the northern coast of Ellef Ringnes Island, near the main ice stream (Massey Sound, source area 4 and outlet arrow on Fig. 1) for the outlet of IIS icebergs during stage 2 (England et al. 2006), is about 6 years, and from the coast of Banks Island, near the major ice stream outlets for the ALIS (Stokes 8 Clark 2001; Stokes et al. 2005), it is about 5 years (Rigor 1992), but could be 40 years or more if the ice is recirculated in the Beaufort Gyre more than once (Fig. 1). Even with much thicker pack ice during OIS 2, icebergs with keels as deep as $800 \mathrm{~m}$ would have moved the 3000$3500-\mathrm{km}$ drift distance with the prevailing currents, in the upper $800 \mathrm{~m}$ of the water column, from the IIS or ALIS to Fram Strait in less than 50-100 years. An ice jam would only occur in the Chukchi Borderland, where ice was grounded, and even this would not have prevented icebergs from deviating northwards around this area. In fact, IRD evidence from several cores for this very pattern of ice drift during OIS 2 was based on lithic grain compositions and Fe grain matches in cores from the central Arctic (Bischof \& Darby 1997). Although the anticyclonic Beaufort Gyre still controls the net motion of ice drift, the ice jam on the Chukchi Borderland forced ice to the north, where it missed the Mendeleev Ridge almost entirely, except for some ice that drifted over this far western area to core 94BC 16 after the Chukchi Borderland ice broke up or before the Chukchi groundings occurred. The northward diversion of ice from the Beaufort Sea area off Alaska might also have caused the icebergs to drift closer to Greenland enroute to Fram Strait, resulting in low quantities of IRD from the IIS and ALIS in the central Arctic cores 94BC16, 94BC20 and 94BC28 (Figs. 4, 5, 6). Because all core sample volumes were similar, the low numbers of grains in at least $94 \mathrm{BC} 16$ and $94 \mathrm{BC} 20$ suggest 


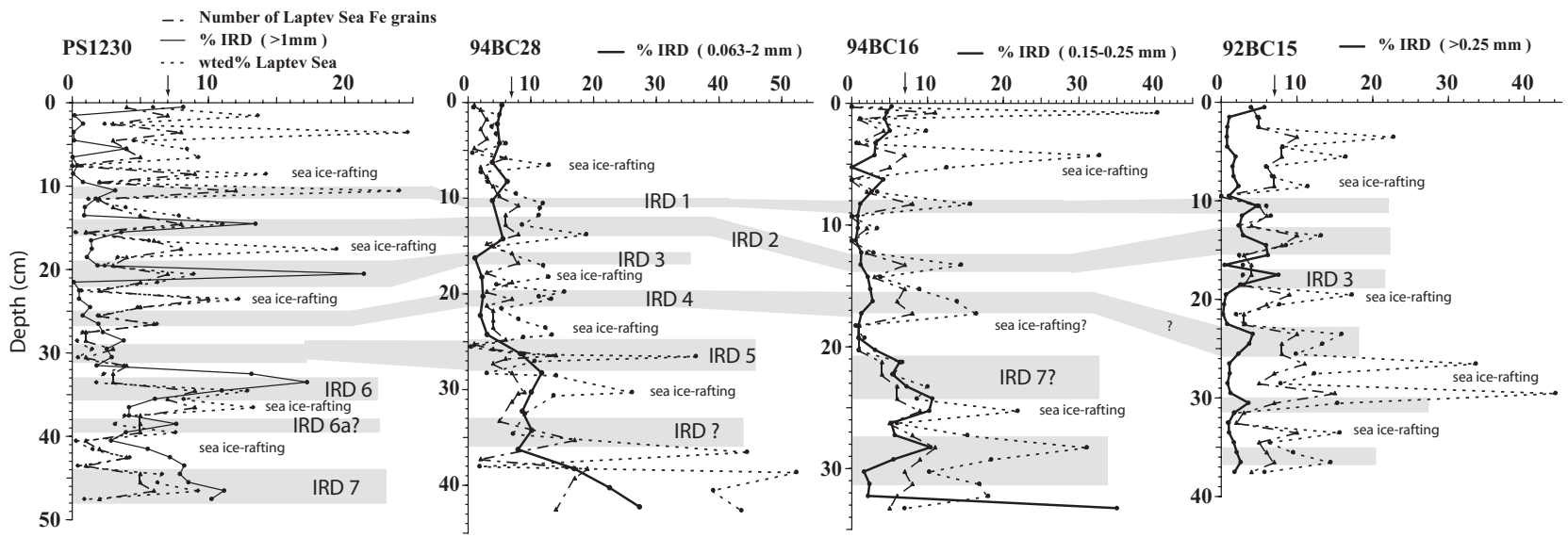

Fig. 8 Fe grains from a sea-ice rafting source, the Laptev Sea, are generally abundant between glacial ice-rafted detritus (IRD) events (shaded as in earlier figures), but also occur during these IRD events.

that fewer ALIS and IIS bergs reached these core sites. Thus, the absence of several IRD events, such as IRD 3 and 6 , in these two cores (94BC16 and 94BC20) might also be related to the diversion of bergs northwards around the Chukchi Borderland as a result of the massive icebergs becoming grounded there. The reappearance of foraminifers in $92 \mathrm{BC} 15$ close to this grounded ice area at 12 Kya (deVernal et al. 2005) probably coincides with the break-up of the grounded ice on the Chukchi Borderland or alternatively with thinner pack-ice conditions. Because ice is funneled through Fram Strait, these IRD events that are missing in the central Arctic cores are well documented in coresPS1230 and PS1231, and ice apparently also reached core $94 \mathrm{BC} 28$ at these times.

\section{Sea-ice IRD}

Because it is possible that some bergs can only transport finer grained sand and mud, there is a slight chance that some of the Fe grain peaks designated as sea-ice rafted might actually be glacial, and that this could change the interpretation of IRD peaks and whether there is a lead from one ice sheet or the other. In order to confirm whether the peaks tentatively identified as sea-ice rafting events are not glacial, the cores containing peaks in ALIS and IIS that do not coincide with coarse IRD peaks are plotted, showing the abundance of Fe grains from the Laptev Sea, an area not known to have been glaciated, at least during the last glacial stage (Fig. 8).

Peaks in Fe grains from the Laptev Sea generally occur both during IRD events and between these events. Except for IRD 1 and 5, the peaks of Laptev Sea Fe grains are smaller during the IRD events than between them. All of the Fe grain peaks in these cores designated as sea-ice IRD show peaks from the Laptev Sea, except for the sea-ice event above IRD 4 in core 94BC16. The large Laptev Sea peaks associated with IRD 1 and 5 hold for all of the cores except 92BC15. Laptev peaks also occur with other IRD events in some cores, suggesting that some sea-ice rafting may have occurred during the glacial IRD events. Sea-ice entrainment that occurred at these times would generally be associated with a lower sea level, when the full breadth of the Arctic shelves was not available for sea-ice entrainment. Thus, entrainment by sea ice, which is restricted to shallow depths $(<30 \mathrm{~m})$, does not require broad shallow shelves. Because anchor ice can entrain large volumes of any size sediment in a restricted area, this might have been an important entrainment process during the last glacial stage.

The coincidence of Fe grains from the Laptev Sea and both the IIS and ALIS between coarse IRD peaks indicates that either the Fe grains from these ice-sheet areas were reworked by sea-ice entrainment on the shelves near the calving areas of these ice sheets, or that bergs with $\mathrm{Fe}$ grains from these ice sheets lacked coarser IRD, or at least did not deposit this coarse IRD along with the Fe grains because of slow melting at the core sites, lower numbers of bergs during these intervals, or some other factor not yet understood about IRD deposition (Darby et al. 2002). Because of the wide geographic distribution of the cores in Fig. 8, it is more likely that the coincidence of the Laptev and ice-sheet sources is primarily the result of sea-ice rafting of all IRD at these times of low coarsegrained IRD. More detailed size analyses of individual Fe grains matched to the ice-sheet sources during both coarse IRD events and between these events might provide further insight into whether these $\mathrm{Fe}$ grains between IRD events were sea-ice rafted. 
Table 1 Number of Fe grains matched to each ice sheet at the lowest point and the highest point in each ice-rafted detritus (IRD) peak.

\begin{tabular}{|c|c|c|c|c|c|c|c|c|c|c|}
\hline \multirow[b]{2}{*}{ Core } & & \multicolumn{9}{|c|}{ low $\rightarrow$ high } \\
\hline & & IRD 1 & IRD 2 & IRD 3 & IRD 4 & IRD 5 & IRD 6 & IRD 7 & IRD? & IRD? \\
\hline \multirow[t]{2}{*}{ PS1230 } & ALIS & $3-9$ & $3-20$ & $11-14$ & $3-16$ & $7-13$ & $2-23$ & $?$ & & \\
\hline & IIS & $5-15$ & $12-19$ & $7-18$ & $5-11$ & $8-18$ & $7-23$ & $7-13$ & & \\
\hline \multirow[t]{2}{*}{ PS1231 } & ALIS & $7-13$ & $4-12$ & $4-15$ & $2-6$ & $4-16$ & & & & \\
\hline & IIS & $13-22$ & $8-17$ & $1-23$ & $3-10$ & $7-13$ & & & & \\
\hline \multirow[t]{2}{*}{ PS1894 } & ALIS & $0-7$ & $2-10$ & $5-22$ & $0-4$ & & & & & \\
\hline & IIS & $1-10$ & $2-9$ & $6-17$ & $1-11$ & & & & & \\
\hline \multirow[t]{2}{*}{$94 \mathrm{BC} 28$} & ALIS & $6-8$ & $3-10$ & $0-7$ & $0-4$ & & & & $2-11$ & $2-9$ \\
\hline & IIS & $6-18$ & $4-10$ & $4-15$ & $5-17$ & & & & $5-22$ & $8-17$ \\
\hline \multirow[t]{2}{*}{$94 \mathrm{BC} 20$} & ALIS & $3-7$ & & & & $2-8$ & & $0-10$ & & $3-4$ \\
\hline & IIS & $2-5$ & & & & $6-9$ & & $5-9$ & & $6-13$ \\
\hline \multirow[t]{2}{*}{$94 \mathrm{BC} 16$} & ALIS & $1-4$ & $3-13$ & & $9-15$ & & & $7-12$ & $1-13$ & \\
\hline & IIS & $4-6$ & $0-11$ & & $2-16$ & & & $1-16$ & $3-11$ & \\
\hline \multirow[t]{2}{*}{$92 \mathrm{BC} 15$} & ALIS & $6-22$ & $12-28$ & 10-20 & $8-15$ & $8-23$ & $5-15$ & & & \\
\hline & IIS & $4-20$ & $11-22$ & $11-22$ & $11-20$ & $6-14$ & $8-12$ & & & \\
\hline
\end{tabular}

\section{What the IRD events represent}

The rapid rise in the Fe grain peaks occurs over core depths of as little as $1 \mathrm{~cm}$, and involves an average increase of between four- and fivefold in the number of Fe grains matched to IIS or ALIS Fe grains (Table 1). For example, in PS1230, IRD 2 and 6, the increase is from 3 to 20 grains and from 2 to 23 grains, respectively. These increases are not just the result of increased melt-out, because the percentage of coarse IRD does not always correspond with these increases and involves less of a change than the Fe grain increase. For example, the $\mathrm{Fe}$ grain peaks in PS1230 at IRD 4 and 5 are much larger than the increase in > 1-mm grains, and the Fe grain peak at IRD 3 is offset from the coarse IRD peak (Fig. 3).

The change for the IIS Fe grains is of similar magnitude as ALIS grains for these and other IRD events. If there were just minor increases in calving from the IIS, there should not be near parity between the Fe grain peaks for the much smaller IIS and the larger ALIS.

Based on the increase in Fe grains over background, Darby et al. (2002) calculated that the ALIS shed about $350 \mathrm{~km}^{3}$ year ${ }^{-1}$, assuming only a threefold increase in $\mathrm{Fe}$ grains above background from the ALIS and a 1.5-Ky duration for an IRD event. The new data presented here show an average increase of between four- and fivefold above background (Table 1). Thus, the earlier estimate may be too low. Clark $\delta$ Stokes (2001) estimated an ice discharge from the ALIS of $>400 \mathrm{~km}^{3}$ year $^{-1}$ based on the morphology of the ice stream area and linear geomorphic features within the ice-stream channel. These estimates are about equal to the estimated ice discharge through Hudson Strait during H events (Stokes et al. 2005). Thus, the ALIS and IIS peaks well above $40 \%$ (Figs. 2-7) are significant ice calving and discharge events in the Arctic.
This does not mean that all or even most of either ice sheet disappeared with each IRD event. Evidence from the QEI occupied by the IIS indicates that this area remained ice covered until the last IRD event around 10 Kya (England et al. 2006). Ice build-up must have occurred over only 2-8 Ky between the IRD events. This requires that some ice mass in these ice sheets survived the rapid calving events, or that the snowfall was much higher than today for this high latitude because large ice sheets usually require tens of thousands of years to form (MacAyeal 1993).

The earliest OIS 2 IRD event involving the IIS began about $36 \mathrm{Kya}$, excluding the uncorrelated IRD event in core 94 BC28 dated by extrapolation to about 50 Kya (Fig. 4). These earlier IRD events are based on only a couple of cores. Still, the IIS must have been established before this time, despite the lack of evidence for the IIS on the QEI (England et al. 2006). This also suggests that if the IIS only developed after the ALIS had reached sufficient elevation to split the jet stream and provide moisture from the Pacific to the IIS, that this occurred prior to 30-36 Kya (Kutzbach \& Wright 1985; Manabe $\delta$ Broccoli 1985; Bush \& Philander 1999).

\section{Sequence and timing of IRD events}

Overall, the most common scenario is that IRD from both ice sheets occurred simultaneously (Table 2). There are nearly an equal number of occasions when either the ALIS or the IIS is leading, especially for IRD 2, in which ALIS led, and IRD 3, in which IIS led more often. But, these occasions are infrequent, and with the large number of simultaneous peaks, the occasions during which Fe grains from one ice sheet occurred first could 
Table 2 Calendar age (Ky) of ice-rafted detritus (IRD) events in Arctic cores and which ice sheet (Arctic portion of the Laurentide Ice Sheet [ALIS] or Innuitian Ice Sheet [IIS]) led.

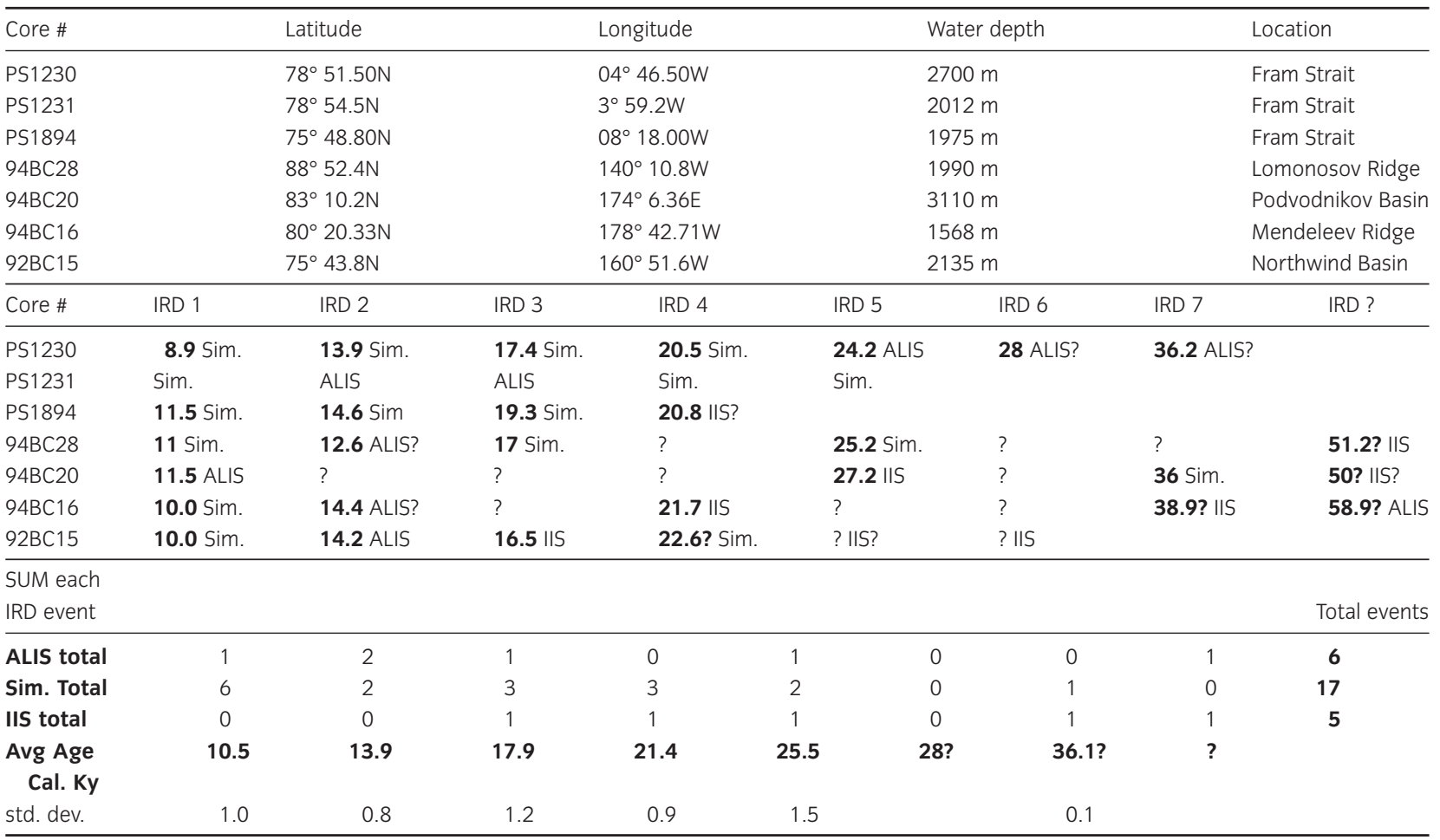

Sim. = both ice sheets occur simultaneously.

Ages correspond to the first Fe grain peak within each coarse IRD event. Thus, ages tend to indicate the earlier part of a calving event.

Average ages for each IRD event, except those older than IRD 5, which are poorly constrained, have standard deviations of about $1 \mathrm{Ky}$.

just be down to chance. Obviously, higher resolution cores from the Arctic are needed for this issue to be resolved.

In nearly all of the cores, the IRD events occurred at about the same time, despite uncertainties in age dates among the Arctic cores (Table 2). In general, these IRD events correspond to $\mathrm{H}$ events in the North Atlantic (Figs. 2-7; Darby et al. 2002). IRD 1 occurred for ALIS Fe grain peaks at an average calendar age of $11.4 \mathrm{Kya}$, and the average age of $\mathrm{HO}$ is $12.2 \mathrm{Kya}$ (Table 2). The Arctic IRD 2 averages at $13.7 \mathrm{Kya}$ and IRD 3 averages at 18.3 Kya: bracketing $\mathrm{Hl}$ at $16.8 \mathrm{Kya}$ (Hemming 2004). IRD 4, 5, 6 and 7 in the Arctic occurred at the average times of 20.5, 25.6, 28 and 36 Kya, respectively, whereas older $\mathrm{H}$ events occurred at 24 (H2), 31 (H3), 38 (H4) and 45 Kya (H5) (Hemming 2004). The differences with $\mathrm{H}$ events partly arise from picking the initial Fe grain peak, which often occurs early in the IRD event, but could well result from low sedimentation rates in the Arctic.

\section{Conclusions}

Glacial IRD events in four Arctic and three Fram Strait cores, based on both coarse IRD and significant numbers of Fe grains from glacial sources (IIS and ALIS) can only be correlated across the Arctic when constrained by radiocarbon dates. This is because of the natural variability of IRD deposition and the fact that sea ice also contributes some coarse IRD, but mostly fine sand $(<250 \mu \mathrm{m})$. Still, correlated glacial IRD events have ages with standard deviations of about $1 \mathrm{Ky}$ or less for most of OIS 2. The five well-constrained IRD events from 11 to 26 Kya have increases of between four- and fivefold in Fe grains from ALIS and IIS sources over core intervals of less than $2-3 \mathrm{~cm}$, indicating a relatively rapid onset of IRD deposition, and most of these peaks persist for similar core intervals, suggesting relatively short-lived events. Thus, much of the ice calving resulted from these brief intervals of partial ice-sheet collapse. The duration between IRD events is too short $(<5 \mathrm{Ky})$ to allow for the complete rebuilding of large ice sheets. Cores with a more complete record of Arctic IRD events and with the best age control, such as core PS1230 in Fram Strait, show good correspondence between IRD and H events (Fig. 2). There are more IRD events than $\mathrm{H}$ events, and commonly IRD events 1 and 4 do not correspond with $\mathrm{H}$ events.

The cores studied thus far have sedimentation rates too low to resolve whether the ALIS or the IIS began calving 
bergs before the other in any consistent manner. Both clearly led some events in some cores, but the most common scenario was simultaneous IRD deposition from both ice sheets. Sea-ice IRD from sources that were not glaciated was common throughout OIS 2 in these cores, and even during many glacial IRD events. This indicates that sea ice was an important transport agent for both glacial and interglacial intervals. Because the sea level was lower for much of OIS 2, the presence of IRD from the Laptev Sea suggests that large expanses of shallow shelves are not required for significant sea-ice entrainment.

\section{Acknowledgements}

This research was funded by the US National Science Foundation grants OPP-0352395, -0136171 and -0550109. Robert Spielhagen kindly provided the Fram Strait core material. Two anonymous reviewers and L. Polyak provided helpful insights that improved the paper.

\section{References}

Andrews J.T. 2000. Icebergs and iceberg rafted detritus (IRD) in the North Atlantic: facts and assumptions. Oceanography 13, 100-108.

Bauch H.A., Mueller-Lupp T., Taldenkova E., Speilhagen R.F., Kassens H., Grootes P.M., Thiede J., Heinemeier J. \& Petryashov V.V. 2001. Chronology of the Holocene transgression at the North Siberian margin. Global and Planetary Change 31, 125-139.

Bischof J.A. \& Darby D.A. 1997. Mid to Late Pleistocene ice drift in the western Arctic Ocean: evidence for a different circulation in the past. Science 277, 74-78.

Bischof J.A. \& Darby D.A. 1999. Quaternary ice transport in the Canadian Arctic and extent of Late Wisconsinan glaciation in the Queen Elizabeth Islands. Canadian Journal of Earth Science 36, 2007-2022.

Bond G., Heinrich H., Broecker W. S., Labeyrie L., McManus J., Andrews J.T., Huon S., Jantschik R., Clasen S., Simet C., Tedesco K., Klas M., Bonani G. \& Ivy S. 1992. Evidence for massive discharges of icebergs into the glacial Northern Atlantic. Nature 360, 245249.

Bond G.C. \& Lotti R. 1995. Iceberg discharges into the North Atlantic on millennial time scales during the last glaciation. Science 267, 1005-1010.

Bush A.B.G. \& Philander S.G.H. 1999. The climate of the Last Glacial Maximum: results from a coupled atmosphere-ocean general circulation model. Jounal of Geophysical Research 104(D20), 24 509-24 525.

Clark C.D \& Stokes C.R. 2001. Extent and basal characteristics of $\mathrm{M}^{\prime}$ Clintock Channel Ice Stream. Quaternal International 86, 81-101.

Darby D.A. 2003. Sources of sediment found in sea ice from the western Arctic Ocean, new insights into processes of entrainment and drift patterns. Journal of Geophysical Research 108(C8), 13-1-13-10.

Darby D.A. \& Bischof J.F. 1996. A statistical approach to source determination of lithic and Fe-oxide grains: an example from the Alpha Ridge, Arctic Ocean. Journal of Sedimentary Research, Section A, Sedimentary Petrology and Processes 66, 599-607.

Darby D.A., Bischof J.F. \& Jones G.A. 1997. Radiocarbon chronology of depositional regimes in the western Arctic Ocean. Deep-Sea Research II 44, 1745-1757.

Darby D.A., Bischof J.F., Spielhagen R.F., Marshall S.A. \& Herman S.W. 2002. Arctic ice export events and their potential impact on global climate during the late Pleistocene. Paleoceanography 17, 15-17.

de Vernal A., Eynaud F., Henry M., Hillaire-Marcel C., Londeix L., Mangin S., Mathiessen J., Marret F., Radi T., Rochon A., Solignac S. \& Turon J.-L. 2005. Reconstruction of sea-surface conditions at the middle to high latitudes of the Northern Hemisphere during the Last Glacial Maximum (LGM) based on dinoflagellate cyst assemblages. Quaternary Science Reviews 24, 897-924.

Dowdeswell J.A., Maslin M.A., Andrews J.T. \& McCave I.N. 1995. Iceberg production, debris rafting, and the extent and thickness of Heinrich layers $(\mathrm{H}-\mathrm{l}, \mathrm{H}-2)$ in North Atlantic sediments. Geology 23, 301-304.

England J., Atkinson N., Bednarski J., Dyke A.S., Hodgson D.A. \& Cofaigh C.O. 2006. The Innuitian Ice Sheet: configuration, dynamics and chronology. Quaternary Science Reviews 25, 689-703.

England J., Sharp M., Lemmen D.S. \& Bednarski J. 1991. On the extent and thickness of the Innuitian Ice Sheet: a postglacial adjustment approach: discussion. Canadian Journal of Earth Science 28, 1689-1695.

Fairbanks R.G., Mortlock R.A., Chiu T., Cao L., Kaplan A., Guilderson T.P., Fairbanks T.W. \& Bloom A.L. 2005. Marine radiocarbon calibration curve spanning 0 to 50,000 years B.P. based on paired ${ }^{230} \mathrm{Th} /{ }^{234} \mathrm{U} /{ }^{238} \mathrm{U}$ and ${ }^{14} \mathrm{C}$ dates on pristine corals. Quaternary Science Reviews 24, 1781-1796.

Forman S.L. \& Polyak L. 1997. Radiocarbon content of pre-bomb marine mollusks and variations in the ${ }^{14} \mathrm{C}$ reservoir age for coastal areas of the Barents and Kara seas, Russia. Geophysical Research Letters 24, 885-888.

Fronval T., Jansen E., Bloemendal J. \& Johnsen S. 1995. Oceanic evidence for coherent fluctuations in Fennoscandian and Laurentide ice sheets on millennium timescales. Nature 374, 443-446.

Grousset F.E., Labeyrie L., Sinko J.A., Cremer M., Bond G., Duprat J., Cortijo E. \& Huon S. 1993. Patterns of ice-rafted detritus in the glacial North Atlantic $\left(40^{\circ}-55^{\circ} \mathrm{N}\right)$. Paleoceanography 8, 175-192.

Grousset F.E., Pujol C., Labeyrie L., Auffret G. \& Boelaert A. 2000. Were the North Atlantic Heinrich events triggered by the behavior of the European Ice sheets? Geology 28, 123-126.

Hemming S.R. 2004. Heinrich events: massive late Pleistocene detritus layers of the North Atlantic and their 
global climate imprint. Review of Geophysics 42, doi:10.1029/ 2003RG000128.

Hillaire-Marcel C., de Vernal A., Polyak L. \& Darb D. 2004. Size dependent isotopic composition of planktic foraminifers from Chukchi Sea vs. northwest Atlantic sediments-implications for the Holocene paleoceanography of the western Arctic. Quaternary Science Reviews 23, 245-260.

Hulbe C.L., MacAyeal D.R., Denton G.H., Kleman J. \& Lowell T.V. 2005. Catastrophic ice shelf breakup as the source of Heinrich event icebergs. Paleoceanography 19 , 1004-1029.

Johnson R.G. \& Lauritzen S-E. 1995. Hudson Bay-Hudson Strait jokulhaups and Heinrich events: a hypothesis. Palaeogeography, Palaeoclimatology, Palaeoecology 117, 123-137.

Kutzbach J.E. \& Wright H.E. 1985. Simulation of the climate of 18,000 years BP: results for the North America/North Atlantic/European sector and comparison with the geological record of North America. Quaternary Science Reviews 4, 147-187.

MacAyeal D.R. 1993. Binge/purge oscillations of the Laurentide Ice Sheet as a cause of the North Atlantic's Heinrich events. Paleoceanography 8, 775-784.

Manabe S. \& Broccoli A.J. 1985. The influence of continental ice sheets on the climate of an ice age. Journal of Geophysical Research 90D, 2167-2190.

Mangerud J. \& Gulliksen S. 1975. Apparent radiocarbon ages of recent marine shells from Norway, Spitsbergen, and Arctic Canada. Quaternary Research 5, 263-273.

Marshall, S.J. \& Clarke G.K.C. 1997. A continuum mixture model of ice stream thermomechanics in the Laurentide Ice Sheet 2. Application to the Hudson Strait Ice Stream. Journal of Geophysical Research 102(B9), 20615-20637.

Nørgaard-Pedersen N., Spielhagen R.F., Erlenkeuser H., Grootes P.M., Heinemeier J. \& Knies J. 2003. Arctic Ocean during the Last Glacial Maximum: Atlantic and polar domains of surface water mass distribution and ice cover. Paleoceanography 18, doi:10.1029/2002PA000781.

Polyak L., Darby D.A., Bischof J. \& Jakobbson M. 2007. Stratigraphic constraints on late Pleistocene glacial erosion and deglaciation of the Chukchi margin, Arctic Ocean, Quaternary Research 67, 234-245.

Polyak L., Edwards M.H., Coakley B.J. \& Jakobsson M. 2001. Ice shelves in the Pleistocene Arctic Ocean inferred from deep-sea bedforms. Nature 401, 453-457.

Rashid H., Hesse R. \& Piper D.J.W. 2003. Origin of unusually thick Heinrich layers in ice-proximal regions of the northwest Labrador Sea. Earth Planetary Science Letters 208, 319-336.

Reimer P.J., Baillie M.G.L., Bard E., Bayliss A., Beck J.W., Bertrand C., Blackwell P.G., Buck C.E., Burr G., Cutler K.B., Damon P.E., Edwards R.L., Fairbanks R.G., Friedrich M., Guilderson T.P., Hughen K.A., Kromer B., McCormac F.G., Manning S., Bronk Ramsey C., Reimer R.W., Remmele S., Southon J.R., Stuiver M., Talamo S., Taylor F.W., van Der Plicht, J. \& Weyhenmeyer C.E. 2004. IntCal04 Terrestrial radiocarbon age calibration, 26-0 ka B.P. Radiocarbon 46, 1029-1058.

Reimnitz E., Kempema E.W. \& Barnes P.W. 1987. Anchor ice, seabed freezing, and sediment dynamics in shallow Arctic seas, Journal of Geophysical Research 92(C13), 14 671-14 678.

Rigor I. 1992. Arctic Ocean buoy program. Argos Newsletter July 44, 1-3.

Rigor I. G. \& Colony R. L. 1997. Sea-ice production and transport of pollutants in the Laptev Sea, 1997-1993, Science of the Total Environment 202, 89-110.

Scourse J.D., Hall I.R., McCave I.N., Young J.R. \& Sugdon C. 2000. The origin of Heinrich layers: evidence from H2 for European precursor events. Earth and Planetary Science Letters 182, 187-195.

Stokes C \& Clark C.D. 2001. Palaeo-ice streams. Quaternary Science Reviews 20, 1437-1457.

Stokes C.R., Clark C.D., Darby D.A \& Hodgson D.A. 2005. Late Pleistocene ice export events into the Arctic Ocean from the M'Clure Strait Ice Stream, Canadian Arctic Archipelago. Global and Planetary Change 49, 139-162.

Stuiver M., Reimer P.J., Bard E., Beck W.E., Burr G.S., Hughen K.A., Kromer B., McCormac F.G., van der Plicht J. \& Spurk M. 1998. INTCAL98 radiocarbon age calibration 0-24,000 BP. Radiocarbon 40, 1041-1083. 